DOI 10.31558/2519-2949.2021.4.3

УДК 329.1/.6:502(477)]:323.02

ORCID ID: https://orcid.org/0000-0002-1107-9258

Бугайчук А. П., Волинський національний університет імені Лесі Украӥнки

\title{
МИРНІ ЗІБРАННЯ ЯК ІНСТРУМЕНТ ВПЛИВУ ЕКОЛОГІЧНИХ ПАРТІЙ ТА ГРОМАДСЬКИХ ОРГАНІЗАЦІЙ НА ПОЛІТИЧНІ ПРОЦЕСИ В УКРАЇ̈I
}

У статті досліджено мирні зібрання як один із інструментів екологічних політичних партій та громадських організацій в контексті їх впливу на політичні процеси в Украйні.

Встановлено, щуо специфіка організаційних особливостей, гасел та інших особливостей мирних зібрань украӥнських екологічних партій та громадських організаиій змінювалися з кіния 1980-х років та в роки незалежності. Зокрема потужним стимулом для їх активізаиії та проведення протестних мирних зібрань стала Чорнобильська катастрофа 1986 року. Станом на 2021 рік спектр проблем, які стають причиною та приводом для мирних зібрань, дуже широкий. Однією із найбільш актуальних стає проблема пом'якшення наслідків негативних змін клімату та адаптації до них.

В рамках дослідження не виявлено суттєвих відмінностей між специфікою використання мирних зібрань екологічними партіями та екологічними громадськими організаціями. Всі суттєві відмінності пов'язані із різним статусом иии організаиій та їх відноменням до виборчого прочесу. Натомість сиенарії мирних зібрання протестного типу (демонстрачії, марші, пікетування), а також акиї позитивного спрямування (прибирання, благоустрій, садіння дерев тощьо) для екологічних партій та громадських організачій в свойх характерних рисах є однаковими.

Напередодні та під час виборчих кампаній спостерігається активізаџія екологічних партій та громадських організаџій у проведенні мирних зібрань. Їх спещифіка залежить від типу виборів: під час загальнодержавних такі акиії бувають як локальними, так і загальнодержавними. Під час місиевих виборів мирні зібрання мають переважно локальний характер та присвячені локальним проблемам.

Популярними типами акиій у виборчий період є акиії протесту із гаслами та вимогами до влади, оскільки у переважній більшості випадків екологічні партії в Украйні знаходяться в опозиції або критично оцінюють дії влади: як на центральному, так і локальному рівні. Екологічні громадські організачії відповідно до свого статусу дають поради та формулюють вимоги до учасників виборів та закликають їх включити екологічні програми та зобов'язання у свої програми, зокрема у формі «екологічного порядку денного».

Ключові слова: екологічні партії, Партія Зелених України, екологічний рух, мирні зібрання, політичні прочеси, виборча кампанія.

Вступ. Процес розвитку української демократії має об'ємну та різноманітну історію мирних зібрань в рамках різних кампаній, масових протестів, «майданів» та інших громадських та політичних кампаній. В цьому контексті одними із організацій, які активно використовують інструмент мирних зібрань $є$ екологічні партії (ЕП) та громадські організації (ГО).

За останні 5 років екологічний та кліматичний рух у світі влаштовував масові марші, страйки, акції тощо. Хоча в Україні ці акції були не найбільш масовими, ЕП та екологічні ГО тут активно використовують публічні акції, марші, флешмоби тощо для досягнення своїх цілей.

Мета дослідження полягає у встановленні специфіки використання ЕП та ГО мирних зібрань, особливостей таких мирних зібрань та інформаційних кампаній, що їх супроводжують. Вона розкривається через такі завдання:

- встановити, які форми мирних зібрань (марші, акції протесту, мітинги тощо) є типовими для ЕП та ГО в Україні;

- визначити, якими були типові гасла та публічно заявлені завдання таких зібрань;

- дослідити специфіку використання мирних зібрань в рамках передвиборчих кампаній ЕП в Україні.

(C) Бугайчук А. П., 2021 
Аналіз попередніх публікацій показує зацікавлення окремих науковців дослідженнями екологічного руху в ретроспективі, екологічних громадських ініціатив, розвитку екологічних партій. Зокрема О. Г. Стегній провів грунтовний соціологічний аналіз екологічного руху в Україні. В. Г. Акопян дослідив використання громадських ініціатив для впровадження екологічної парадигми. М. Алексієвець провела ретроспективний аналіз розвитку екологічного руху в Україні не тільки у роки незалежності, але і з часів Київської Русі. І. Г. Коваленко дослідила розвиток Партії зелених України вже за роки незалежності до 2007 року, а також методи діяльності ПЗУ.

Актуальність даного дослідження полягає у тому, що станом на 2021 рік і надалі в міру загострення проблеми зміни клімату та посилення техногенного навантаження, що призводить до негативного впливу на довкілля на території України, може зростати кількість приводів та загострюватися причини для масових мирних зібрань, в тому числі акцій протесту проти погіршення екологічної та кліматичної ситуації. Лідерами цього руху вже $\epsilon$ ЕП та ГО, для яких суспільний запит на політичне лідерство в даному контексті може стати потужним стимулом для подальшого розвитку.

\section{Результати дослідження}

Еволюція специфіки «екологічних» мирних зібрань в Україні. Мирні зібрання були однією із важливих форм діяльності ЕП та ГО в Україні впродовж років незалежності. Ще до здобуття незалежності важливим чинником, який провокував посилення екологічного руху та в тому числі проведення мирних зібрань, стала Чорнобильська катастрофа 1986 року. Спроби влади замовчувати наслідки катастрофи та невідповідні очікуванням природоохоронних активістів заходи із ліквідації наслідків посилили екологічний компонент національно-демократичного руху в Україні. В багатьох регіонах України розпочалися перші мирні акції протесту проти атомної енергетики. Вже через два роки після трагедії - 26 квітня 1988 року в Києві відбулася демонстрація із гаслами «Геть АЕС з України», «УКК - за без'ядерну Україну», «Не хочемо мертвих зон», «АЕС - на референдум», «Промисловість, землю, воду - під екологічний контроль», «Кожному - персональний дозиметр». На цьому підгрунті також сформувалися і екологічні об'єдання нового, опозиційного характеру: «Зелений світ» та Союз «Чорнобиль»[1].

Окрім гасел, які стосувалися атомної енергетики, екологічні ГО просували закриття чи зміни у роботі інших промислових підприємств, які шкодили довкіллю, і зміни парадигми «підкорення природи», яку поширювали у СРСР на державному рівні. Як зазначає Т. Ю. Перга, «особливістю українського екологічного руху зазначеного періоду $є$ тісний зв'язок з національним і правозахисним рухом, які були складовими більш широкого протестного руху, що охопив більшість регіонів України. Адже як політичні, так i екологічні вимоги, що висували учасники протестів i мітингів, спрямовувалися на зміну існуючого політичного режиму» [2].

Зі здобуттям незалежності в 1991 році екологічний рух отримав більше можливостей для розвитку без суттєвих репресій із боку влади. Також з'явилася необхідна законодавча база для політичного плюралізму та роботи неурядових організацій у сфері захисту довкілля. В результаті у представників екологічного руху з'являються можливості проводити мирні зібрання не тільки протестного характеру. Також у 1991 році частина активістів Всеукраїнської екологічної асоціації «Зелений світ» створили зареєстрували Партію зелених України (ПЗУ) - першу екологічну партію [3].

Л. Ковпак відзначає, що у цей час зусилля активістів екологічного руху були зосереджені на вдосконаленні регулювання питань охорони природи та запровадженні мораторію на спорудження AEC [4]. Варто відзначити, що і станом на 2021 рік ці два напрямки залишаються одними із ключових. Водночас відрізняється частота згадування проблеми змін клімату у гаслах, програмних документах та маніфестах ЕП. Наприклад, Всеукраїнська екологічна асоціація «Зелений світ», яка була заснована однією із перших, виникла на як реакція громадянського суспільства на Чорнобильську катастрофу, тому боротьба із атомною енергетикою була ключовою тематикою. Натомість станом на 2021 рік у їх маніфестах ця проблема є лише однією із багатьох. «УЕА «Зелений світ» наголошує на цілому ряді серйозних екологічних проблем суто внутрішнього характеру, що пов'язані зі специфікою виробничої інфраструктури, нерівномірним розподілом сировинних ресурсів, специфікою географічної зональності її території. Винятковою особливістю для України є те, що екологічно гострі локальні ситуації в Придніпров'ї, Донбасі, Північному Криму, Карпатах, Поліссі, на узбережжі Чорного та Азовського морів поступово перетворюються в регіональні екологічні кризові ситуації. Україну не оминули такі небезпечні явища, як кислотні дощі, транскордонне забруднення, руйнування родючого шару грунтів, зміни клімату, накопичення відходів, особливо токсичних і 
радіаційних, проблеми питної води, зниження природного потенціалу біологічного різноманіття», йдеться на їх офіційному сайті [5].

Саме така політематичність гасел та тематики мирних зібрань ЕП та ГО характерна для них і на даний час. Водночас в самій системі таких організацій існує часткова спеціалізація. Наприклад, одна із двох активних станом на 2021 рік екологічних партій «Екологічна альтернатива» переважно працює в місті Києві. На місцевих виборах 2020 року вони висунули кандидатів лише тут. Більшість публічних акцій партії також відбуваються в столиці [6].

Існує і тематичне розшарування екологічних ГО на ті, що спеціалізуються на природоохоронній діяльності, на захисників прав тварин, борються зі змінами клімату, забрудненням екосистем, за якісніше та глибше сортування відходів, справедливу трансформацію «брудних» галузей промисловості тощо.

Типові форми мирних зібрань. У статті 39 Конституції України вказано, що «громадяни мають право збиратися мирно, без зброї і проводити збори, мітинги, походи і демонстрації, про проведення яких завчасно сповіщаються органи виконавчої влади чи органи місцевого самоврядування». Із законодавства ми запозичили типологію форм таких заходів: збори, мітинги, походи і демонстрації. На практиці багато заходів складно строго віднести строго до тієї чи іншої категорії, адже з 1996 року, коли прийняли Конституцію, виникло багато інших, більш сучасних форм мирних зібрань та гібридних акцій, коли мирне зібрання є лише частиною більшої інформаційної кампанії. Тим не менш, нас цікавлять лише ті заходи, які мають свої публічні гасла та задеклароване бажання донести щось до груп інтересів, влади, бізнесу тощо. Натомість внутрішні збори партій та ГО або непублічні заходи тут не розглядаються, адже вони не $\epsilon$ інструментом прямого впливу на інших суб'єктів політичного процесу.

Традиційно популярними для ЕП та ГО є акції із прибирання довкілля. Такі акції дуже наочно демонструють, що вони хочуть прибрати негативні наслідки впливу людини на довкілля. Іноді із ними поєднують акції із садіння дерев чи інших форм озеленення чи благоустрою території. Наприклад, наші попередні дослідження агітації ПзУ показують, що для них акції із садіння дерев, а також прибирання $\epsilon$ частиною ширшого порядку денного щодо боротьби із проблемою забруднення територій ліквідації нелегальних сміттєзвалищ, збереження зелених зон у містах [7].

Тим не менш, подібні акції із прибирання і озеленення давно перестали бути в Україні суто специфічними для ЕП та ГО. Станом на 2021 рік існує навіть ініціатива Президента України (який не представляє цей ідеологічний напрямок) щодо масового заліснення територій [8]. Акції із прибирання територій зокрема підтримують і на державному рівні, хоча екологічні партії не мають представників у владі на центральному рівні. Також подібні акції часто організовують органи місцевого самоврядування $[9,10]$.

Натомість більш специфічними для ЕП та ГО є акції протесту та марші, які переплітаються із законодавчо окресленими категоріями мітингів, походів та демонстрацій. Багато із них спричинені існуванням гострої, на думку учасників, проблеми та мають певні вимоги.

Наприклад, громадська організація UAnimals спеціалізується на боротьбі за права тварин. В рамках своєї роботи вони організовують акції для захисту прав тварин на законодавчому рівні, борються із живедерами тощо. Зокрема у 2021 році вони провели масштабний Марш за права тварин у м. Києві «з вимогою захистити тварин від жорстокості та заборонити цирки з тваринами, контактні зоопарки та дельфінарії, заборонити хутрові ферми та притравочні станції, зупинити діяльність живодерів-догхантерів, а також контролювати виконання чинних законів, які захищають тварин від жорстокості». За твердженням організаторів, у акції взяли участь «тисячі українців, підприємців, артистів, волонтерів, студентів, пенсіонерів і ветеранів». Метою загальноукраїнського маршу було спонкування Президента України, уряду та Верховної Ради України (ВРУ) до прийняття відповідного законодавства, а також ефективніше контролювати виконання чинного законодавства у природоохоронні сфері [11].

Схожу тактику використовують організатори Кліматичних маршів. Такі акції стараються проводити одночасно у різних населених пунктах у формі маршу з однієї символічної точки в іншу із певними гаслами та візуальними символами. Основну акцію проводять у Києві, де, на думку організаторів, більше шансів «достукатися» до представників влади, які приймають рішення щодо кліматичної політики в Україні. Наприклад, у 2019 році Кліматичний марш в м. Київ, за даними організаторів, зібрав понад 2000 людей. Також акції провели у 21 місті в Україні. «Марш завершився біля Офісу Президента, де активісти виголосили промови до нової української влади. Відкритий лист 3 шістьма кліматичними вимогами Маршу публічно підписали керівники організацій, що ініціювали Марш, та передали представникові ОП Сергію Мельнику. Услід за символічним листом, активісти 
надішлють і офіційне звернення із тими ж вимогами»,- відзначають у ГО «Екодія», яка була співорганізатором акції [12].

Також як реакція на забруднення чи потенційне забруднення довкілля або порушення екологічних прав відбуваються акції протесту та навіть спроби блокування роботи підприємствзабруднювачів. Так, у м. Рівне ГО «Екоклуб» 2019 року бореться проти спорудження та роботи деревообробного підприємства, яке, на їх думку, суттєво зашкодить мешканцям прилеглих територій. В рамках цієї кампанії вони разом із активними мешканцями громади організовували акції протесту та навіть перекривали дороги з метою зупинити спорудження заводу [13].

Подібні акції використовували і політичні партії. Так, партія «Екологічна альтернатива» (ЕА) разом з іншими організаціями провела серію публічних акцій із вимогою притягнути до відповідальності людину, яку звинувачують у системному знущанні над тваринами. Оскільки справу розглядають у суді, саме майданчик перед судом став локацією для демонстрацій.

Не завжди мирні зібрання на екологічну тематику мають негативні емоційні акценти. Так, вже згадана партія ЕА у вересні 2021 року провела «екологічне свято» у мікрорайоні Биківня м. Київ. Ця локація відома зокрема тим, що довгий час мешканці борються за збереження лісу в умовах активного розширення площ багатоквартирної забудови. «Це один із заходів, який ми організували. Він неформатний. Зазвичай для екоактивістів - це стояти десь із плакатами, щось вимагати, або прибирати, або когось бити. Ми вирішили отак нестандартно із сім'ями зібратися, поспілкуватися, познайомитися», - відзначив представник партії С. Волков [14].

В результаті проведеного аналізу нам не вдалося виокремити суттєвих та системних відмінностей між тим, які мирні зібрання проводять ЕП та екологічні ГО. Відмінності між ними зумовлені лише статусом. Так, екологічним ГО не обов'язково проводити з'їзди для висування кандидатів на виборах, інші заходи, передбачені згідно із законодавством, яке стосується політичних партій. Також у період виборів вони апелюють до кандидатів, а не пропонують свою програму дій. Натомість загадані марші, акції протесту, акції із озеленення, «екологічні свята» тощо загалом характерні для обох типів суб'єктів.

Ми виділяємо дві ключові причини цього. По-перше, в Україні політичні партії в Україні залишаються доволі слабко інституціоналізованими. Це стосується і ЕП. Наприклад, партія ЕА стала екологічною незадовго до і місцевих виборів 2020 року і до цього не працювала саме в такому форматі. «Еко партія Берези» теж виникла як проєкт створений напередодні місцевих виборів 2020 року. Частина екоактивістів стали членами цих партій суто для участі у виборах, або навіть балотувалися від них, не вступаючи у партії [15].

Специфіка мирних зібрань під час виборів. Як і більшість інших політичних партій та ГО, екологічні проводять акції на політичну тематику, в тому числі мирні зібрання перед виборами. Причому, якщо порівнювати, наприклад, президентські та парламентські вибори 2019 року із місцевими виборами 2020 року, кількість публічно висвітлених мирних зібрань ЕП та ГО була суттєво більшою [7].

Для цього є дві об'єктивні передумови. По-перше, під час президентських та парламентських виборів партії та ГО переважно ведуть загальноукраїнські кампанії щодо загальнодержавних проблем. Бувають винятки, які стосуються кандидатів у одномандатних округах чи локальних екологічних проблем, проте основний фокус тут - на масштабні проблеми. Це сприяє тому, що кількість мирних зібрань може бути меншою, проте ці заходи можуть бути масовішими, адже проблеми і гасла зазвичай стосуються масштабних проблем. Натомість під час місцевих виборів місцеві осередки партій ведуть окремі кампаніі. Також загальний фокус політичних процесів також змішується на локальні проблеми, що стимулює і проведення більшої кількості мирних зібрань у окремих громадах, де відбуваються вибори. Це може бути, наприклад, окреме сміттєзвалище, чи питання відкриття біля населеного пункту шкідливого виробництва.

Друга передумова стосується специфіки ЕП та ГО. Як вже зазначено вище, потужним стимулом для розвитку екологічного руху в Україні у перші роки незалежності та навіть у роки «перебудови» СРСР була Чорнобильська катастрофа. Станом на 2021 рік тако існують глобальні об'єднавчі тематики як зміни клімату. Проте результати нашого аналізу показують, що більшість мирних зібрань ЕП та особливо екологічних ГО стосуються локальних проблем. Це може бути закриття переповненого сміттєзвалища, зупинення знищення скверу чи вирубки лісу, притягнення до відповідальності власників конкретного підприємства-забруднювача.

Саме в контексті виборів гасла акцій протесту на екологічну тематику зміщуються в бік критики влади, якщо екологічна партія чи ГО в опозиції до неї. Наприклад, у жовтні 2020 року осередок ПЗУ у м. Дніпро провів символічну акцію «поховання природи» під стінами міської ради. Таким чином 
опозиційна партія хотіла «достукатися до чиновників», які «нищать дерева, занедбали парки, річки та закривають очі на промислові викиди» [16].

У 2020 році в Новомосковській громаді Дніпропетровської області осередок ПЗУ організовував акції протесту, які прямо не стосувалися екологічної тематики. У них виникли труднощі із реєстрацією для участі у місцевих виборах, тому право балотуватися потрібно було доводити у судовому порядку. В цьому випадку акції протесту були спрямовані на окружну виборчу комісію та суд, щоб добитися права брати участь у виборах [17].

У Луцькій міській громаді Волинської області передвиборча кампанія на місцевих виборах 2020 року висуванців від «Еко партії Берези» частково була побудована на їх попередньому досвіді боротьби проти забруднення повітря у місті неприємними запахами в рамках кампанії «За чисте повітря. Луцьк» [18]. За рік до того у місті гостро постала ця проблема, тому вона була на порядку денному багатьох політичних сил. Зокрема висуванці від «Еко партії Берези» обіцяли «екоаудит міста з вирішенням проблем смороду та сміття», а також «будівництво сучасного сміттєпереробного заводу». Формами мирних зібрань, які використовували в рамках кампанії «За чисте повітря. Луцьк», були мітинги, публічні зустрічі із відповідальними посадовцями, громадські рейди і патрулювання для фіксування джерел забруднення [19].

Висновки. Форми та тематика мирних зібрань ЕП та ГО еволюціонували як в міру розвитку самих організацій, так і відповідно до зміни об'єктивних обставин, зокрема гостроти різних екологічних проблем, які поставали на загальнодержавному та локальному рівнях. Потужним стимулом наприкінці 1980-х-початку 1990-х років стала Чорнобильська катастрофа. Тематикою, на яку звертають значно більше уваги станом на 2021 рік порівняно із 1990-ми роками, стали зміни клімату.

Серед типових форм мирних зібрань «протестного» типу для ЕП та ГО варто відзначити акції протесту, марші, пікетування підприємств-забруднювачів. Також типовими для них $\epsilon$ акції 3 «позитивним» акцентом: садіння дерев, прибирання та озеленення територій, інший благоустрій, де буквально «очищають» довкілля від негативного впливу людини. В окремих випадках йдеться про проведення розважальних публічних заходів екологічного спрямування.

У передвиборчий період ЕП та екологічні ГО активізуються у проведенні мирних зібрань різного спрямування. Для політичних партій типовими є акції протесту проти дій влади, якщо вони знаходяться в опозиції, а також агітаційні заходи для донесення до виборців своєї програми, гасел, намірів тощо. Екологічні ГО активізуються у проведенні заходів для привернення уваги учасників виборів до екологічної тематики та свого порядку денного. Залежно від типу виборчої кампанії (вибори Президента України, ВРУ чи місцеві) змінюються акценти мирних зібрань протестного спрямування. Під час виборів Президента та ВРУ ЕП та екологічні ГО більше роблять акцент на загальноукраїнських екологічних проблемах, а під час місцевих - на локальних.

\section{Бібліографічний список:}

1. Інформаційні матеріали до річниці аварії на Чорнобильській АЕС. Матеріали Українського інституту національної пам'яті. URL: https://uinp.gov.ua/informaciyni-materialy/zhurnalistam/informaciyni-materialy-dorichnyci-avariyi-na-chornobylskiy-aes (дата звернення: 30.09.2021).

2. Перга Т. Ю. Роль Української Гельсінської спілки в розвитку екологічного руху в Україні. Матеріали Українського інституту національної пам'яті. URL: https://uinp.gov.ua/informaciyni-materialy/ dopovidi/konferenciya-ugs/rol-ukrayinskoyi-gelsinskoyi-spilky-v-rozvytku-ekologichnogo-ruhu-v-ukrayini (дата звернення: 30.09.2021).

3. Історія Партії Зелених України. URL: http://greenparty.ua/istoriya/ (дата звернення: 30.09.2021).

4. Ковпак Л. В. Екологічний рух// Енциклопедія історії України: Т. 3: Е-Й / Редкол.: В. А. Смолій (голова) та ін. НАН України. Інститут історії України. - К.: В-во «Наукова думка», 2005. - 672 с.: іл.. URL: http://www.history.org.ua/?termin=Ekologichny_rukh (дата звернення: 30.09.2021).

5. Історія Української екологічної асоціації «Зелений світ». Офіџійна сторінка асоиіачіï.

URL: http://www.zelenysvit.org.ua/?page=about (дата звернення: 30.09.2021).

6. Програма партії. Офічійний сайт партії «Екологічна альтернатива».

URL: https://alternative.com.ua/category/propositions/ (дата звернення: 30.09.2021).

7. Бугайчук А. П. Особливості агітації Партії Зелених України в місцевих виборах 2020 року. Вісник Львівського університету. Серія філос.-політолог. студії. 2021. Випуск 36, с. 173-182.

DOI: 0.30970/PPS.2021.36.21. (дата звернення: 30.09.2021).

8. Глава держави дав старт проекту «Зелена країна», спрямованому на захист природи та довкілля в Україні. Офіційне інтернет-представництво Президента Украӥни.

URL: https://www.president.gov.ua/news/glava-derzhavi-dav-start-proektu-zelena-krayina-spryamovanom-68865 (дата звернення: 30.09.2021). 
9. Україна відзначає Міжнародний день чистих берегів: Міністр Роман Абрамовський прибирав у київському Гідропарку. Міністерство захисту довкілля та природних ресурсів Украӥни.

URL: https://mepr.gov.ua/news/38098.html (дата звернення: 30.09.2021).

10. У Луцьку триває екологічна толока «Чисте довкілля». Офіційний сайт Луцької міської ради.

URL: https://www.lutskrada.gov.ua/publications/u-lutsku-tryvaie-ekolohichna-toloka-chyste-dovkillia (дата звернення: 30.09.2021).

11. Україна вийшла на Всеукраїнський марш за права тварин! Oфiuiйна cmopiнка ГO UAnimals. URL: https://www.facebook.com/UAnimals.official (дата звернення: 30.09.2021).

12. Понад 2000 людей, 21 місто, 6 вимог і одна планета. Як українці вийшли на кліматичний марш.

ГО «Екодія». URL: https://ecoaction.org.ua/klimatychnyj-marsh-2019.html (дата звернення: 30.09.2021).

13. Безпечна промисловість. Офіиійна сторінка ГО «Екоклуб».

URL: https://ecoclubrivne.org/kronospan_campaign/ (дата звернення: 30.09.2021).

14. Ekoweekend у Биківні. Офіційна сторінка партії «Екологічна альтернатива.

URL: https://fb.watch/8ddgHbh-dW/ (дата звернення: 30.09.2021).

15. Работягова І. В., Мовчан У. І., Мосенцева Т. С., Крисенко О. В. «Особливості функціонування українських політичних партій як акторів українського політичного ринку». Аналітична записка. Регіональний філіал НІСД у м. Харкові. URL: https://niss.gov.ua/doslidzhennya/politika/osoblivostifunkcionuvannya-ukrainskikh-politichnikh-partiy-yak-aktoriv (дата звернення: 30.09.2021).

16. Хода на пам'ять довкілля Партії Зелених України м. Дніпро. Yоитиbе-канал Дніпропетровськоі ОО Партії Зелених Украӥни. URL: https://www.youtube.com/watch?app=desktop\&v=o0D_hKFuD40 (дата звернення: 30.09.2021).

17. Звернення Новомосковської міської організації Партії Зелених України Дніпропетровської області до мешканців Новомосковська. Офіиійна сторінка «Партія Зелених Украӥни Новомосковськ». URL: https://www.facebook.com/100016379520787/videos/738325993390045/ (дата звернення: 30.09.2021).

18. Передвиборча програма Волинської обласної організації Політичної партії «ЕКО ПАРТІЯ БЕРЕЗИ» до Луцької міської ради. Офіційний портал Центральної виборчої комісії України.

URL: https://www.cvk.gov.ua/pls/vm2020/showpprogp6511=95pt001f01=695pid102=878.doc (дата звернення: 30.09.2021).

19. Ініціатива «За чисте повітря. Луцьк». URL: https://www.facebook.com/cleanairlutsk (дата звернення: 30.09.2021).

\section{References:}

1. Information materials on the anniversary of the Chernobyl accident. Materials of the Ukrainian Institute of National Memory. URL: https://uinp.gov.ua/informaciyni-materialy/zhurnalistam/informaciyni-materialydo-richnyci-avariyi-na-chornobylskiy-aes (access date: 30.09.2021).

2. Perga T. The role of the Ukrainian Helsinki Union in the development of the environmental movement in Ukraine. Materials of the Ukrainian Institute of National Memory. URL: https://uinp.gov.ua/informaciynimaterialy/dopovidi/konferenciya-ugs/rol-ukrayinskoyi-gelsinskoyi-spilky-v-rozvytku-ekologichnogo-ruhu-v-ukrayini (access date: 30.09.2021).

3. History of the Green Party of Ukraine. URL: http://greenparty.ua/istoriya/ (access date: 30.09.2021).

4. Kovpak L. Ecological movement [Electronic resource] // Encyclopedia of the History of Ukraine:

Vol. 3/ Editor .: VA Smoliy (chairman) and others. NAS of Ukraine. Institute of History of Ukraine.K .: Рub. «Наукова думка», 2005. - 672 p. - URL: http://www.history.org.ua/?termin=Ekologichny_rukh (access date: 30.09 .2021 ) .

5. History of the Ukrainian Ecological Association "Green World". Official page of the association. URL: http://www.zelenysvit.org.ua/?page=about (access date: 30.09.2021).

6. The party program. The official website of the party "Environmental Alternative". URL: https://alternative.com.ua/category/propositions/ (access date: 30.09.2021).

7. Buhaichuk A. Features of the agitation of the Green Party of Ukraine in the 2020 local elections. Bulletin of Lviv University. Series philosopher-political science. 2021. Issue 36, p. 173-182. DOI: 0.30970 / PPS.2021.36.21. (access date: 30.09.2021).

8. The President launched the Green Country project aimed at protecting nature and the environment in Ukraine. Official Internet Representation of the President of Ukraine. URL: https://www.president.gov.ua/news/glava-derzhavidav-start-proektu-zelena-krayina-spryamovanom-68865 (access date: 30.09.2021).

9. Ukraine celebrates the International Day of Clean Shores: Minister Roman Abramovsky cleaned the Kyiv Hydropark. Ministry of Environmental Protection and Natural Resources of Ukraine. URL: https://mepr.gov.ua/news/38098.html (access date: 30.09.2021).

10. The ecological clean-up "Clean Environment" continues in Lutsk. Official site of Lutsk City Council. URL: https://www.lutskrada.gov.ua/publications/u-lutsku-tryvaie-ekolohichna-toloka-chyste-dovkillia (access date: 30.09.2021).

11. Ukraine took part in the All-Ukrainian March for Animal Rights! Official page of UAnimals NGO. URL: https://www.facebook.com/UAnimals.official (access date: 09/30/2021). 
12. More than 2000 people, 21 cities, 6 requirements and one planet. How Ukrainians went on a climate march. NGO "Ecodia". URL: https://ecoaction.org.ua/klimatychnyj-marsh-2019.html (access date: 09/30/2021).

13. Safe industry. Official page of the NGO "Ecoclub". URL: https://ecoclubrivne.org/kronospan_campaign/ (access date: 09/30/2021).

14. Ecoweekend in Bykivnia. Official page of the party "Environmental Alternative.

URL: https://fb.watch/8ddgHbh-dW/ (access date: 09/30/2021).

15. Rabotyagova I., Movchan V., Mosentseva T., Krysenko O., "Features of the functioning of Ukrainian political parties as actors in the Ukrainian political area." Analytical note. NISS Regional Branch in Kharkiv. URL: https://niss.gov.ua/doslidzhennya/politika/osoblivosti-funkcionuvannya-ukrainskikh-politichnikh-partiy-yak-aktoriv (access date: 30.09.2021).

16. Walk in memory of the environment of the Green Party of Ukraine in Dnipro. Youtube channel of the Dnipro branch of the Green Party of Ukraine. URL: https://www.youtube.com/watch?app=desktop\&v=o0D_hKFuD40 (access date: 09/30/2021).

17. Address of the Novomoskovsk city organization of the Green Party of Ukraine of the Dnipropetrovsk region to the residents of Novomoskovsk. Official page of the Green Party of Ukraine Novomoskovsk.

URL: https://www.facebook.com/100016379520787/videos/738325993390045/ (access date: 30.09.2021).

18. Election program of the Volyn regional organization of the Political Party "ECO PARTY OF BERESA" to the Lutsk City Council. Official portal of the Central Election Commission of Ukraine.

URL: https://www.cvk.gov.ua/pls/vm2020/showpprogp6511=95pt001f01=695pid102=878.doc (access date: 30.09.2021).

19. Initiative "For clean air. Lutsk". URL: https://www.facebook.com/cleanairlutsk (access date: 09/30/2021).

\section{Buhaichuk A. P. Peaceful assemblies as a tool for the influence of environmental parties and NGOs on political processes in Ukraine}

The article examines peaceful assemblies as one of the tools of environmental political parties and NGOs in the context of their impact on political processes in Ukraine.

It is established that the specifics of organizational aspects, slogans and other features of peaceful assemblies of Ukrainian environmental parties and NGOs have changed since the late 1980s and during the years of the independence of Ukraine. In particular, the 1986 Chernobyl disaster was a powerful stimulus for their intensification and peaceful protest rallies. As of 2021, the range of issues that are the cause and reason for peaceful assemblies is very wide. One of the most pressing is the problem of mitigating the effects of negative climate change and adapting to them.

The study does not reveal any significant differences between the specifics of the use of peaceful assemblies by environmental parties and environmental NGOs. All significant differences are related to the different status of these organizations and their connection to the electoral process. Instead, the scenarios of peaceful protest-type gatherings (demonstrations, marches, pickets), as well as positive actions (cleaning, landscaping, planting trees, etc.) for environmental parties and NGOs are identical in their characteristics.

On the eve and during the election campaigns, there is an intensification of environmental parties and NGOs in holding peaceful assemblies. Their specificity depends on the type of elections: during national elections, such actions are both local and national. During local elections, peaceful assemblies are predominantly local and address local issues.

Popular types of actions during the election period are protests with slogans and demands to the government, as in the vast majority of cases environmental parties in Ukraine are in opposition or critically evaluate actions of the government: both at the central and local levels. Environmental NGOs, in accordance with their status, provide advice and formulate requirements to election participants and encourage them to include environmental aspects and commitments in their programs, in particular in the form of an «environmental agenda».

Keywords: environmental parties, the Green Party of Ukraine, environmental movement, peaceful assemblies, political processes, election campaign. 